\title{
Fungus ball in concha bullosa
}

\author{
Konka bülloza içinde mantar topu
}

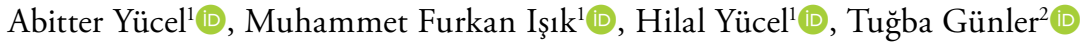 \\ ${ }^{1}$ Department of Otolaryngology, Health Sciences University, Konya Training and Research Hospital, Konya, Turkey \\ ${ }^{2}$ Department of Pathology, Health Sciences University, Konya Training and Research Hospital, Konya, Turkey
}

\begin{abstract}
Fungus ball (FB) is a non-invasive form of fungal hyphae in the sinus cavity, usually involving the maxillary sinus. The most common type of fungal sinusitis involving the paranasal sinus region is FB. In this article, we would like to draw the attention of otorhinolaryngologists by presenting a case of a $\mathrm{FB}$ with an interesting localization.
\end{abstract}

Keywords: Concha bullosa, endoscopic sinus surgery, fungus ball.

Fungus ball $(\mathrm{FB})$ is a non-invasive fungal hyphae in the sinus cavity, usually seen in the maxillary sinus. Likewise, the most common type of fungal sinusitis that affects the paranasal region is the FB. ${ }^{[1]}$ The actual incidence of sinonasal FB is not known exactly; however, it has a tendency to increase particularly in the last two decades. ${ }^{[1,2]}$ Although $\mathrm{FB}$ originating from concha bullosa $(\mathrm{CB})$ is quite rare, there has been an increase in the number of patients with $\mathrm{CB} F B$. In this case report, we discuss the findings and complaints of a patient with $\mathrm{FB}$ in the $\mathrm{CB}$.

\section{CASE REPORT}

A 41-year-old female patient was admitted to our clinic with complaints of nasal obstruction, anosmia and headache. From patient history, it was determined that the patient did not have any chronic disease. Her complaints continued despite oral antibiotic
$\ddot{O} Z$

Mantar topu (MT) genellikle maksiller sinüsü tutan, sinüs boşluğunun invaziv olmayan bir fungal hifa türüdür. Paranazal sinüs bölgesini tutan en yaygın fungal sinüzit tipi MT’dir. Bu yazıda, ilginç yerleşimli bir MT olgusu sunularak kulak burun boğaz uzmanlarının ilgisi çekilmeye çalışıldı.

Anahtar sözcükler: Konka bülloza, endoskopik sinüs cerrahisi, mantar topu.

treatments. On endoscopic examination, patient had left nasal septum deviation and bilateral inferior concha hypertrophy. Computed tomography (CT) scan was taken and a mass image consistent with soft tissue in the right middle concha which is also obstructing the right osteomeatal complex was detected (Figure 1). Under general anesthesia, septoplasty was first performed and then the lateral lamella of the right middle concha was excised. A soft, wet sand-like mass was found in the conchal cavity (Figure 2). The mass was removed and the operation site was irrigated and suctioned. The mass was sent for microbiological and pathological investigation. There was no reproduction in culture. Histopathological investigation confirmed fungal hyphae colonization (Figure 3). Postoperative period was unremarkable for the patient and she is still being followed-up in our clinic. A written informed consent was obtained from the patient.

Received: January 8, 2019 Accepted: April 28, 2019 Published online: September 03, 2019

Correspondence: Abitter Yücel, MD. SBÜ Konya Eğitim ve Araştırma Hastanesi, Kulak Burun Boğaz Hastalıkları Kliniği, 42090 Meram, Konya, Turkey. e-mail: abitteryucel@hotmail.com 


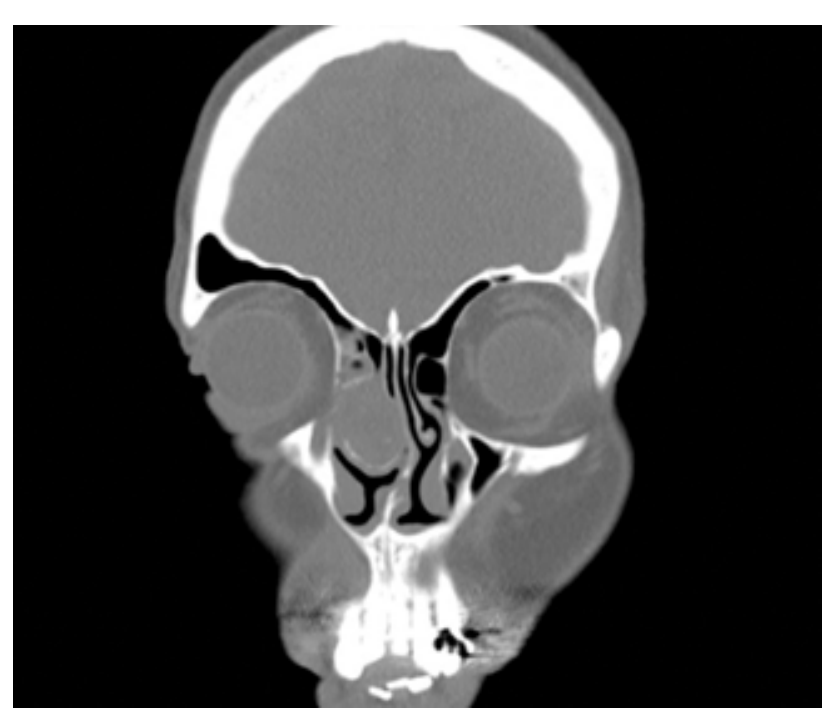

Figure 1. Right concha bullosa is filled with soft tissue as seen on coronal sections of computed tomography.

\section{DISCUSSION}

Concha bullosa is the most common variation of the paranasal sinuses. Otorhinolaryngologists may encounter $\mathrm{CB}$ cases such as mucocele, ossifying fibroma, cholesteatoma, and $\mathrm{FB}^{[3]}$ Although $\mathrm{CB}$ is widespread, $\mathrm{FB}$ in the $\mathrm{CB}$ is uncommon. Yoon et al. ${ }^{[2]}$ reported that endoscopic sinus surgeries (ESS) performed for FB cases have increased steadily in the last 20 years. While the percentage of FB cases in total endoscopic sinus surgery cases was $3.55 \%$ in 1996 , this ratio increased to $13.99 \%$ in 2015 . Otorhinolaryngologists cannot establish a clear reason for this increase; however, perhaps this situation occurred because of the following reasons: improved diagnostic methods and imaging modalities, unnecessary increase in the use of broad spectrum antibiotics, increased endodontic approaches, and decreased mucociliary clearance due to aging. ${ }^{[2,4]}$

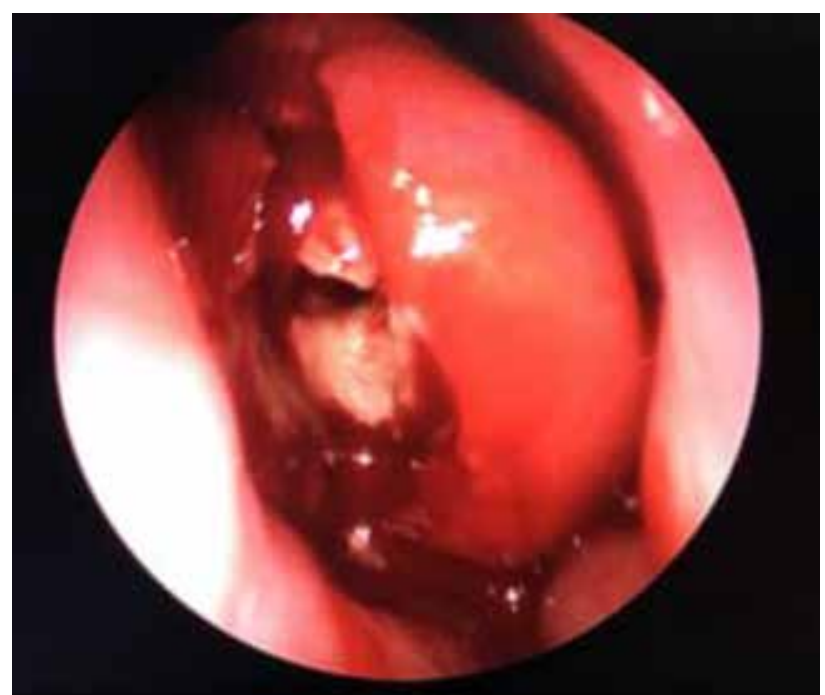

Figure 2. Mass inside right concha bullosa (lateral half of concha was excised).

The pathogenesis of sinonasal FB is not clear. One of a number of theories puts forward the use of dental materials containing zinc oxide. When this material reaches sinuses, it can create a suitable environment for the growth of fungus. Another possible reason is the anaerobic environment due to ostial blockage. In other words, the inhibition of sinonasal air flow plays an important role in the pathology of this disease. ${ }^{[1]}$ Our patient also had antibiotic treatments due to the sinonasal infections in previous clinical applications. Decreased drainage and ventilation of $\mathrm{CB}$ may have established the basis for FB formation in this patient. Recent reports have shown that there is no correlation between the FB localization and the form of septum deviation, $\mathrm{CB}$ and Haller cell. ${ }^{[1,2]}$ However, it has also been reported that the maxillary sinus FB is more often seen at the concave part of a deviated septum in male patients. ${ }^{[5]}$
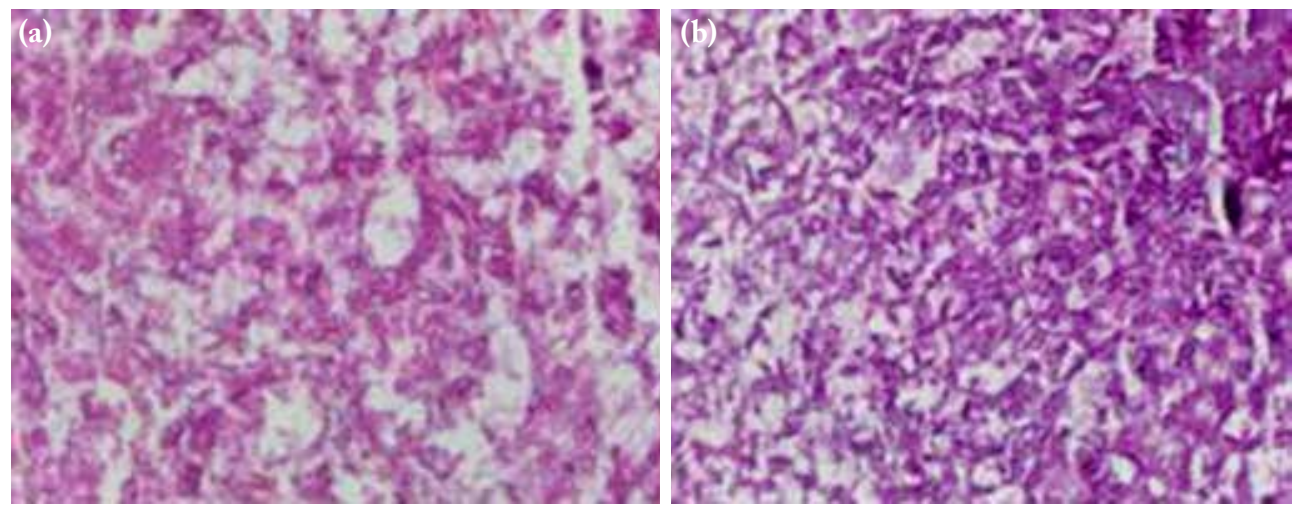

Figure 3. (a) Fungal hyphae colonization in fibroid material $(\mathrm{H}-\mathrm{E} \times 600)$. (b) Irregularly branched, broad, empty-looking fungal hyphae (periodic acid-Schiff $\times 600$ ). 
Patients with sinonasal FB may be asymptomatic. Even though patient complaints would change according to the localization of $\mathrm{FB}$, the most common symptoms are headache, nasal obstruction and nasal discharge. ${ }^{[4]}$ Unlike patients with chronic rhinosinusitis, complaints of patients with $\mathrm{FB}$ are unilateral and it can also be found incidentally. ${ }^{[2]}$ In the case of $\mathrm{FB}, \mathrm{CT}$ is the generally preferred diagnostic procedure. Computed tomography usually shows opacification of the sinus cavity, sclerosis and erosion of bone structures. Magnetic resonance imagining may be considered when bone erosion is seen in $\mathrm{CT} .^{[1]}$

Surgery is the treatment modality for FB. Complete removal of $\mathrm{FB}$ should be undertaken and sinonasal airflow should be established. Surgery is recommended even if the patient is asymptomatic. ${ }^{[2,6]}$

A review of the literature has shown that cases of $\mathrm{FB}$ in the CB have gradually increased in the past 10 years. This can be attributed in particular to the increased use of imaging methods and the increased number of ESS operations in recent years. In particular, we believe that the endoscopic view of FB may be useful for otorhinolaryngologists. Thus, we wished to increase the awareness of clinicians on FB by presenting this case.

\section{Declaration of conflicting interests}

The authors declared no conflicts of interest with respect to the authorship and/or publication of this article.

\section{Funding}

The authors received no financial support for the research and/or authorship of this article.

\section{REFERENCES}

1. Lim HS, Yoon YH, Xu J, Kim YM, Rha KS. Isolated sphenoid sinus fungus ball: a retrospective study conducted at a tertiary care referral center in Korea. Eur Arch Otorhinolaryngol 2017;274:2453-9.

2. Yoon YH, Xu J, Park SK, Heo JH, Kim YM, Rha KS. A retrospective analysis of 538 sinonasal fungus ball cases treated at a single tertiary medical center in Korea (1996-2015). Int Forum Allergy Rhinol 2017;7:1070-5.

3. Cukurova I, Demirhan E, Karaman Y, Yigitbasi OG. Extraordinary pathologic entities within the concha bullosa. Saudi Med J 2009;30:937-41.

4. Kim JS, So SS, Kwon SH. The increasing incidence of paranasal sinus fungus ball: a retrospective cohort study in two hundred forty-five patients for fifteen years. Clin Otolaryngol 2017;42:175-9.

5. Oshima H, Nomura K, Sugawara M, Arakawa K, Oshima T, Katori Y. Septal deviation is associated with maxillary sinus fungus ball in male patients. Tohoku J Exp Med 2014;232:201-6.

6. Ozkırıs M, Kapusuz Z, Seçkın S, Saydam L. Fungus ball in concha bullosa: a rare case with anosmia. Case Rep Otolaryngol 2013;2013:920406. 